\title{
Calculation Method for Predicting AMO Isc from High Altitude Aircraft Flight Data
}

\section{Matthew G. Myers, David B. Snyder (Ret.) NASA Glenn Research Center, Cleveland, Ohio 44135}

\section{Introduction}

High altitude aircraft are used by the space photovoltaic (PV) community to estimate the air mass Zero (AMO) performance of solar cells, however a correction of around 1 to 4 percent is needed due to atmospheric effects. Shown here is the correction method for NASA's ER-2 calibration platform.

\section{Method}

The Isc and temperature of a solar cell are measured over a range of high altitudes while monitoring ambient pressure. The ER-2 flights typically range from $70,000 \mathrm{ft}(\mathrm{AM}=\mathbf{0 . 0 4})$ to $55,000 \mathrm{ft}(\mathrm{AM}=\mathbf{0 . 0 7})$. The cell Isc data are corrected for the effects of atmospheric ozone and cell temperature followed by a Langley plot extrapolation and earth-sun distance correction to estimate the AMO performance of the solar cell. This process takes the following inputs:

\section{Data}

AM0 Spectral Model

Units
$\mathrm{nm}, \mathrm{W} / \mathrm{m}^{2} \mathrm{~nm}$
$\mathrm{~nm}, \mathrm{mDU}-1$
$\mathrm{~nm}$, decimal
Atm., Amps, $\mathrm{K}$
atm, DU
$\mu \mathrm{A} / \mathrm{K}$
degrees
$\mathrm{AU}$

\section{Source}

ASTMG173 [1]

NREL Solar Spectral Model [2]

Experimentally determined

Experimentally determined

TOMS, OMI on Aura satellite [3]

Experimentally determined

NOAA website [4]

NASA Landsat 7 handbook

\section{Ozone and Temperature Correction:}

Each flight Isc value is individually corrected first for ozone with equations (1) and (2), and then for temperature using equation (3) where:

lozc: Ozone corrected Isc Isc: Measured Isc

$P_{A M 0}(\lambda)$ : Model of AMO irradiance $P(\lambda) \quad$ Ozone attenuated irradiance $\operatorname{EQE}(\lambda)$ : Solar cell EQE

Oz: Est. optical path ozone

Itc: Temp. corrected Isc

Tt: Target temperature

Tc: Measured cell temperature

a: $\quad$ Cell Isc temp. coefficient

$\beta(\lambda)$ : Ozone abs. spectrum

$$
\begin{aligned}
& I_{o z c}=I_{s c} \frac{\int P_{A M 0}(\lambda) E Q E(\lambda) d \lambda}{\int P(\lambda) E Q E(\lambda) d \lambda} \text { (1) } \quad P(\lambda)=P_{A M 0}(\lambda) e^{-\beta(\lambda) O_{z}(2)} \\
& I_{t c}=I_{o z c}+\left(T_{T}-T_{C}\right) \alpha(3)
\end{aligned}
$$

\section{Langley plot method and Heliocentric Distance Correction:}

The log of the corrected Isc is plotted as a function of airmass. A linear fit is used to extrapolate this plot to AMO and the log is reversed to give an Isc value. This is then corrected for earth-sun distance by multiplying the Langley plot value by the distance in $\mathrm{AU}$ squared.

[1] rredc.nrel.gov/solar/spectra/am1.5/astmg173/astmg173html, ASTM G173-03, Extraterrestrial Radiation

[2] Bird, R., and Riirdan, C.. "Simple Solar Spectral Model for Direct and Diffuse Irradiance on Horizontal and Tilted Planes at the Earth3 Surface for Cloudless Atmospheres", SERI/TR-215-2436, December 1984

[3] ftp//toms.gsfc.nasa.gov/pub/omi/data/ozone, NASA Total Ozone Mapping Spectrometer satellite [4] http://www.esrl.noaa.gov/gmd/grad/solcalc/, NOAA Solar Calc.

\section{SCHACK Software}

The SCHACK (Solar Cell High Altitude Correction Calculator) software uses this method as depicted in the flowchart below. For each data point, the program estimates the ozone column and corrects for ozone attenuation. The Isc is then temperature corrected and ambient pressures converted to airmass. The AMO Isc is then estimated with a Langley plot and corrected for earth-sun distance.
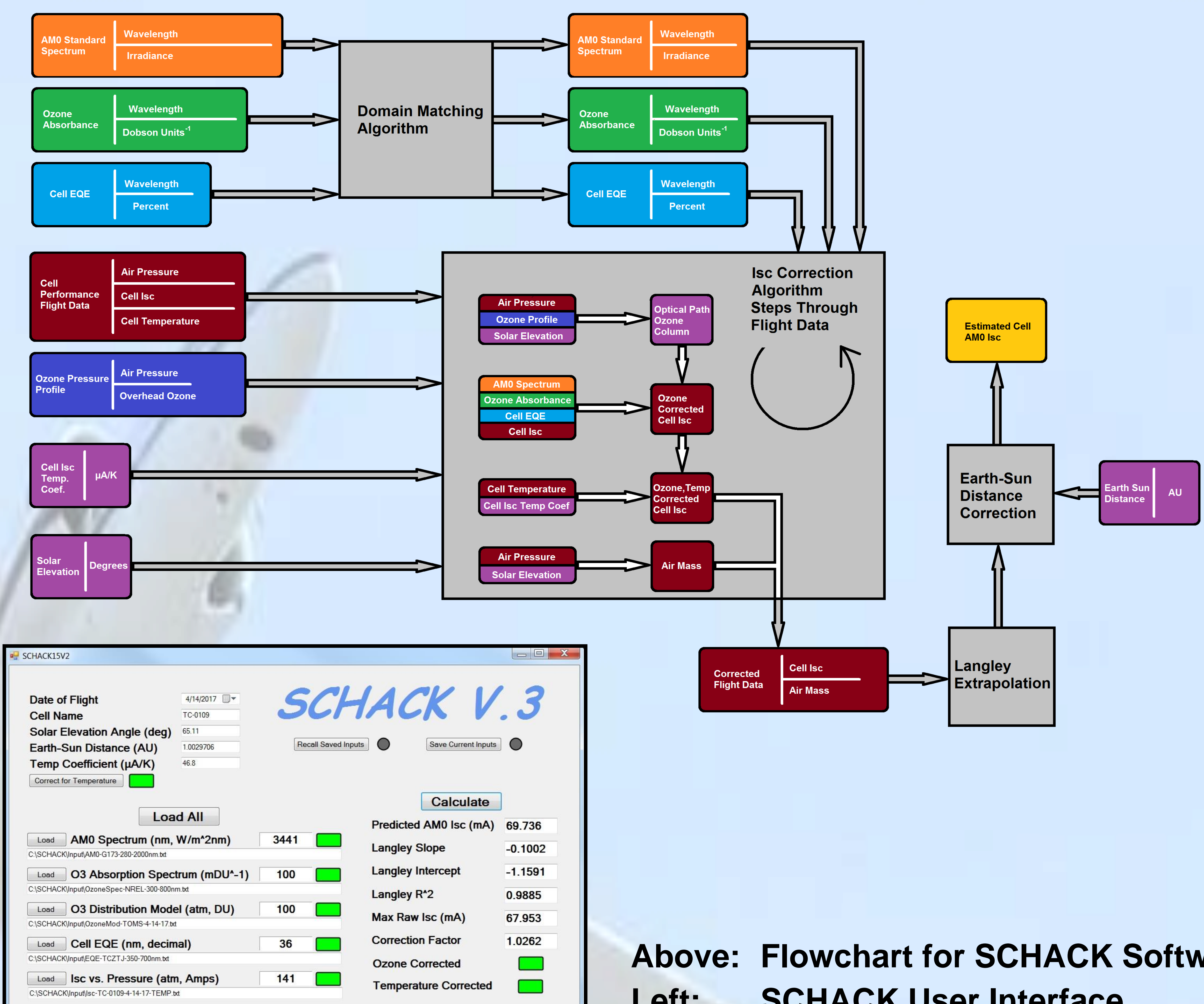

Above: Flowchart for SCHACK Software Left: $\quad$ SCHACK User Interface

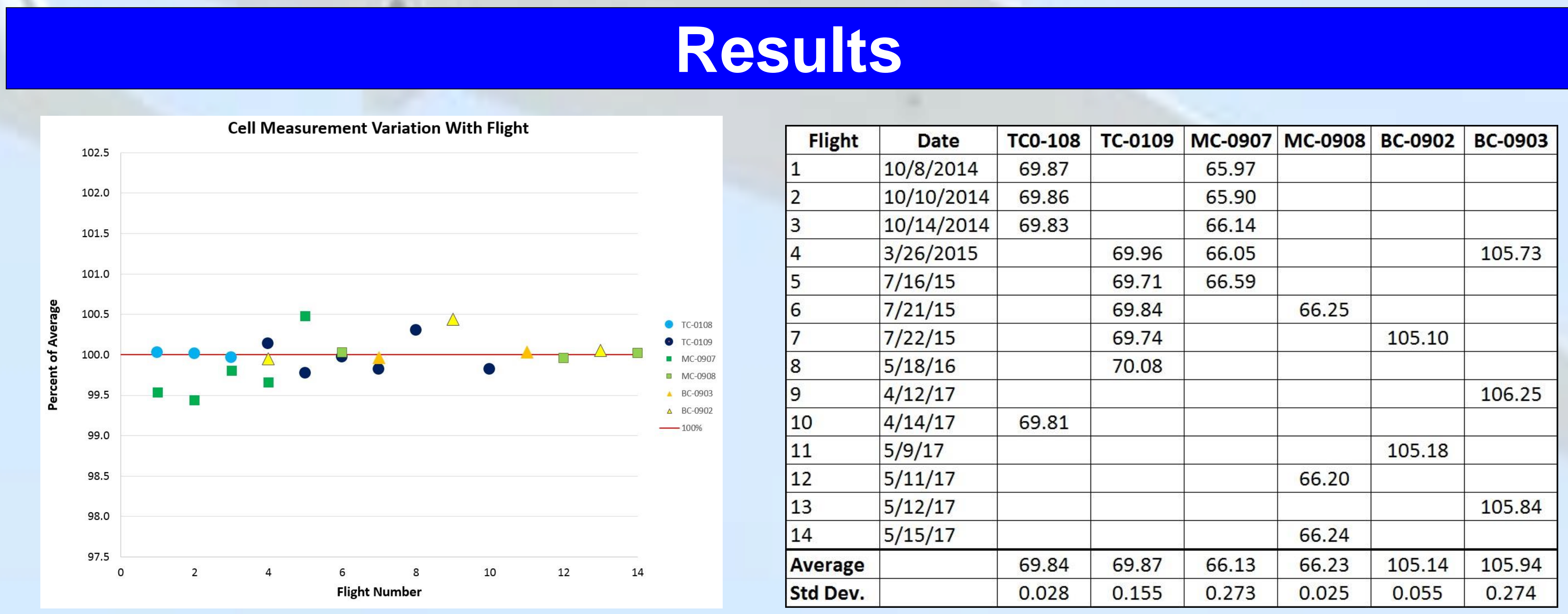

ER-2 Data:

Four years of AMO Isc estimates from two sets of $3 \mathrm{~J}$ isotypes are depicted in the chart and table above and show generally good repeatability despite varying flight conditions.

High Altitude Balloon Comparison:

A CNES PV measurement experiment onboard the CASOLBA balloon flown in April of 2017 measured an IMM four-junction cell previously flown on the ER-2. The AMO Isc estimate from the CASOLBA balloon differed from the ER-2 estimate by less than $0.2 \%$ 